\section{INORGANIC NITROGEN OVER THE WESTERN NORTH ATLANTIC OCEAN}

\author{
D. R. Hastie, ${ }^{1}$ S. Malle, ${ }^{1}$ D. L. Toom, ${ }^{1}$ \\ D. M. Whelpdale, ${ }^{2}$ W. C. Keene, ${ }^{3}$ \\ J. N. Galloway, ${ }^{3}$ J. Maben, ${ }^{3}$ \\ and A. A. P. Pszenny ${ }^{4}$
}

\begin{abstract}
The concentrations of the reactive nitrogen species $\mathrm{NO}_{2}, \mathrm{NO}_{\mathrm{x}}\left(=\mathrm{NO}+\mathrm{NO}_{2}\right), \mathrm{NO}_{\mathrm{y}}$ (the sum of all compounds of nitrogen and oxygen with the exception of $\mathrm{N}_{2} \mathrm{O}$ ), particulate $\mathrm{NO}_{3}^{-}$, and volatile $\mathrm{NO}_{3}^{-}$were measured from ship and aircraft platforms over the western North Atlantic Ocean as part of the GCE/CASE/WATOX experiment. Air masses sampled were divided into continentally influenced and typical marine on the basis of trajectories, and radon and black carbon measurements. From the $\mathrm{NO}_{3}^{-}$measurements on size separated aerosol and the altitude variations of volatile $\mathrm{NO}_{3}^{-}$and particulate $\mathrm{NO}_{3}^{-}$, a significant interaction between volatile $\mathrm{NO}_{3}^{-}$and sea salt aerosol was indicated. The average marine concentrations measured were: $18 \mathrm{nmol} \mathrm{m}^{-3}$ for $\mathrm{NO}_{2}, 29 \mathrm{nmol} \mathrm{m}^{-3}$ for $\mathrm{NO}_{\mathrm{x}}, 46 \mathrm{nmol} \mathrm{m}^{-3}$ for $\mathrm{NO}_{\mathrm{y}}$, and $10 \mathrm{nmol} \mathrm{m} \mathrm{m}^{-3}$ for total inorganic $\mathrm{NO}_{3}^{-}$. The reactive nitrogen species were present at concentrations some 40 times those encountered in the remote Pacific Ocean, whereas the inorganic $\mathrm{NO}_{3}^{-}$was only 3 times higher.
\end{abstract}

\footnotetext{
${ }^{\mathrm{I}}$ Department of Chemistry and Centre for Atmospheric Chemistry, York University, North York, Ontario, Canada.

${ }^{2}$ Atmospheric Environment Service, North York, Ontario, Canada.

${ }^{3}$ Department of Environmental Sciences, University of Virginia, Charlottesville.

${ }^{4}$ Ocean Chemistry Division, NOAA Atlantic

Oceanographic and Meteorological Laboratory, Miami, Florida.
}

\section{Copyright 1990}

by the American Geophysical Union.

Paper number 90GB02116. 0886-6236/90/90GB-02116\$10.00

\section{INTRODUCTION}

The North Atlantic Ocean is surrounded by continental areas which contain a number of the world's largest pollutant emitters. Industry in North America and Europe, and slash and burn agriculture in Central Africa emit huge amounts of $\mathrm{C}, \mathrm{S}$, and $\mathrm{N}$ compounds into the atmosphere, which prevailing winds regularly transport over the ocean. The anthropogenically enhanced concentrations of these elements may have a direct impact on the biogeochemical cycling of these elements in the marine and atmospheric environments. In addition, the presence of elevated concentrations of odd nitrogen would likely perturb the natural oxidative capacity of the atmosphere over the ocean and have an indirect impact on the biogeochemical cycling of $\mathrm{O}, \mathrm{C}, \mathrm{S}$, and $\mathrm{N}$ itself over the North Atlantic Ocean region. Of all the world's oceans, the North Atlantic is the most influenced by anthropogenic inputs, so it is the first area in which the impact of anthropogenic activity on the marine atmospheric and surface water environments would be discernible.

Since the pollutant sources are almost exclusively on the continents, it is possible to examine a polluted air mass as it moves off the continent over the ocean without the complication of additional inputs. The North Atlantic Ocean is therefore a somewhat simplified system on which to examine the fate of pollution in the environment. While many of the processes may be specific to the particular region under study, the results from such a simplified system may assist in the overall understanding of processes that occur as the pollutants are transported from their source regions.

A number of studies, some completed but most ongoing, have been made on the atmosphere over the North Atlantic Ocean. The Western Atlantic Ocean Experiment (WATOX) has focused on the magnitude and fate of selected nitrogen, 
sulphur, organic, and trace metal compounds advected from the continent of North America to the westem Atlantic Ocean [Galloway et al., 1987; Galloway and Whelpdale, 1987]. The Atmosphere/Ocean Chemistry Experiment (AEROCE) has established a number of long-term stations to study the chemical cycling of a variety of trace species that play an important role in the atmospheric and marine biogeochemical cycles over and in the Atlantic Ocean [Levy, 1988]. The STRATOZ III program has performed a number of flights around the perimeter of the Atlantic Ocean [Rudolph et al., 1987; Drummond et al., 1988]. Several ship-based measurement programs have also been conducted [e.g., Church et al., 1990]. These programs have all shown the continents to have a significant impact on the composition of the atmosphere over the North Atlantic Ocean.

In the summer of 1988 the National Oceanic and Atmospheric Administration (NOAA) ship Mt. Mitchell conducted a cruise in the North Atlantic Ocean as part of the GCE/CASE/WATOX (Global Change

Expedition/Coordinated Air-Sea Experiment/WATOX) program. There were atmospheric and oceanic components to the cruise, with the aim of the atmospheric component being to obtain data on the dynamics of chemical cycling over the North Atlantic Ocean. An overview of the cruise and the experiments is given by Pszenny et al. [1990a].
The current paper uses the nitrogen species data obtained on the first leg of the cruise, from Virginia to Bermuda, to address some aspects of nitrogen chemistry over the ocean. Of particular importance are the speciation and concentrations of the nitrogen compounds over the ocean and the degree of continental influence on these concentrations.

\section{EXPERIMENT}

During the GCE/CASE/WATOX cruise the Mt. Mitchell encircled a large area of the North Atlantic Ocean (Figure 1). To augment the measurements from the ship platform, aircraft overflights were conducted close to the North American east coast and in the vicinity of Bermuda to obtain vertical profiles of species concentrations. This paper focusses on leg 1 of the cruise, which commenced in Norfolk, Virginia, on July 15, 1988 (Julian day 197), and ended at Bermuda on July 29, 1988 (Julian day 211).

The nitrogen oxides are conveniently divided into two groups on the basis of their reactivity. There are the reactive species, such as $\mathrm{NO}, \mathrm{NO}_{2}$ (or their sum, $\mathrm{NO}_{\mathrm{x}}$ ), and peroxyacetyl nitrate (PAN) which, since they have lifetimes of the order of minutes to hours, must be measured in situ, preferably with fast response instruments. The more stable inorganic nitrates, such as $\mathrm{HNO}_{3}$ and particulate $\mathrm{NO}_{3}^{-}$, can

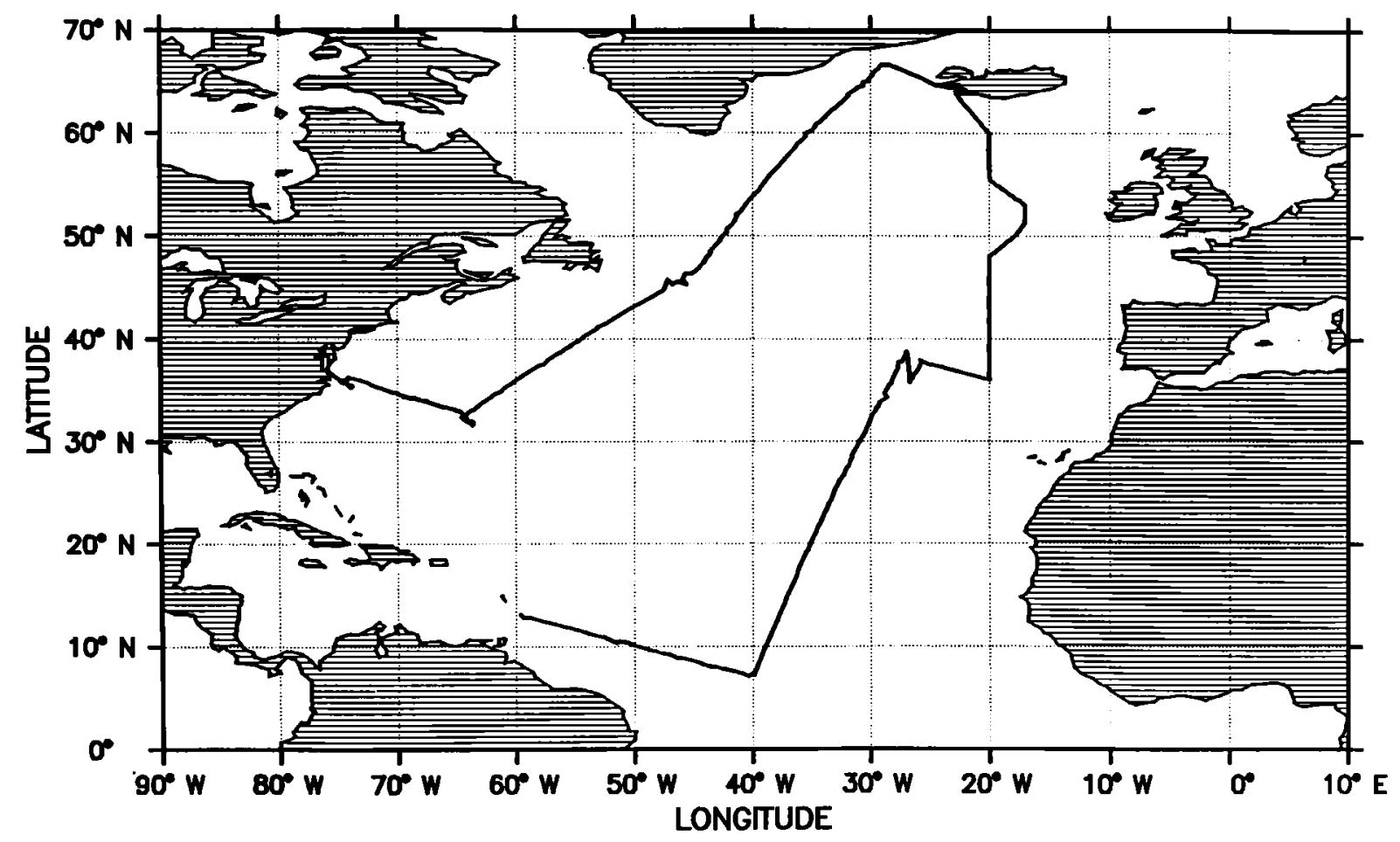

Fig. 1. Map of the North Atlantic Ocean indicating the track of the NOAA vessel Mt. Mitchell for the 1988 Global Change Expedition. 
be collected on filters and returned to the laboratory for analysis. $\mathrm{NO}_{\mathrm{y}}$, which includes all compounds of nitrogen and oxygen with the exception of $\mathrm{N}_{2} \mathrm{O}$, must also be measured in situ. There were in situ and filter systems on both the aircraft and the ship.

The aircraft system for reactive nitrogen measurements, and the results obtained, are described by Ray et al. [1990] and will not be discussed here. On the ship, $\mathrm{NO}_{2}, \mathrm{NO}_{\mathrm{x}}$, and $\mathrm{NO}_{\mathrm{y}}$ were measured with a commercial luminol detector, a Unisearch LMA-3 with LNC-3 converter unit operated with the manufacturer's solutions [Drummond et al., 1989]. The ozone scrubber supplied was found to absorb $\mathrm{NO}_{2}$ and so was removed from the inlet line. $\mathrm{NO}_{2}$ was measured directly by the instrument. $\mathrm{NO}_{\mathrm{x}}$ was measured by passing the air through a chromium trioxide converter to transform the $\mathrm{NO}$ into $\mathrm{NO}_{2}$ prior to analysis for $\mathrm{NO}_{2}$. $\mathrm{NO}_{\mathrm{y}}$ was measured using a gold converter with carbon monoxide as the reducing agent, which converted the nitrogen species to NO [Fahey et al., 1985], which was then oxidized by the chromium trioxide and measured as $\mathrm{NO}_{2}$. This reactive nitrogen instrumentation was housed behind the bridge. Separate inlet systems were installed on booms extending $3 \mathrm{~m}$ outboard off the bridge wings on each side of the ship and operated such that samples were always collected from the windward side. Teflon filters $(1 \mu \mathrm{m})$ were placed at the ends of all lines to protect against sea salt contamination. Since it will be suggested that sea salt scavenges volatile $\mathrm{NO}_{3}^{-}$from atmospheric samples, it is possible that some of the $\mathrm{NO}_{\mathrm{y}}$ concentrations reported here are underestimated. To minimize losses of polar $\mathrm{NO}_{\mathrm{y}}$ species to the walls of the inlet system prior to conversion, gold converters were placed at the end of each inlet line. A single $\mathrm{NO}$ to $\mathrm{NO}_{2}$ converter was used for both inlet systems. A schematic of the sampling system is given in Figure 2. The instrument performed a zero check, by passing the air sample through a ferrous sulphate reducer,

Portside Inlet

Starboard Inlet

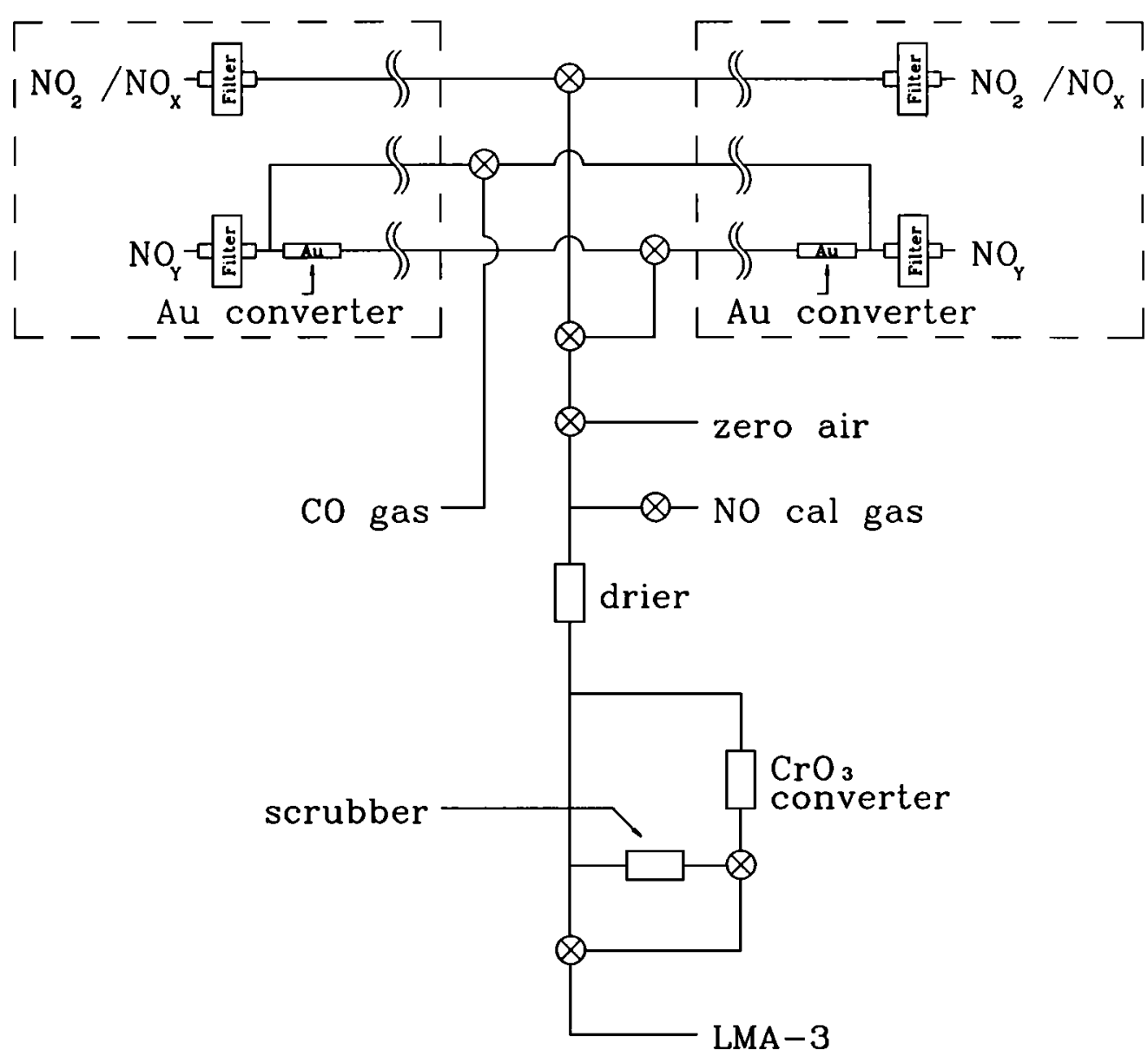

Fig. 2. Schematic diagram of the inlet system used for the reactive nitrogen monitor. 
for 6 min at the top of each hour. The remainder of the hour was broken into 18-min cycles which in turn comprised 6 min of each of $\mathrm{NO}_{2}, \mathrm{NO}_{x}$, and $\mathrm{NO}_{\mathrm{y}}$ measurements. Calibrations were performed daily in the $\mathrm{NO}_{x}$ mode using an NO standard prepared by precisely diluting a certified NO standard (Scott Speciality Gases) to approximately 5 parts per billion by volume (ppbv). The $\mathrm{NO}_{2}$ concentration from the instrument was corrected for instrument non linearity and ozone interference [Drummond et al., 1989]. The errors introduced by these corrections became significant below 100 part per trillion (pptv) and were of the same order as the measurements at $50 \mathrm{pptv}$; thus even though Drummond et al. [1989] claim such a configuration will have a detection limit of 5 pptv for $\mathrm{NO}_{2}$, for this data set the detection limit was 50 pptv. There were no PAN measurements on this leg of the cruise so it was not possible to correct for the known PAN interference. Measurements over this area show PAN concentrations below 20 pptv [Bottenheim and Gallant, 1987; Rudolph et al., 1987]. Using 0.2 as the instrument sensitivity to PAN [Drummond et al., 1989] suggests that neglecting this interference would overestimate $\mathrm{NO}_{2}$ and $\mathrm{NO}_{\mathrm{x}}$ by less than 4 pptv.

Three institutions measured particulate $\mathrm{NO}_{3}^{-}$and volatile $\mathrm{NO}_{3}^{-}$(largely $\mathrm{HNO}_{3}$ but possibly including contibutions from organic nitrates and $\mathrm{N}_{2} \mathrm{O}_{5}$ ) using filter techniques on leg 1 . The three groups operated a total of four samplers on the ship. The Atmospheric Environment Service (AES) triple filter pack [Anlauf et al., 1985] trapped particles on the front Teflon filter and volatile $\mathrm{NO}_{3}^{-}$on the second nylon filter of a three-filter system. The NOAA Atlantic Ocean Marine Laboratory (AOML) had two systems, a high volume (hi-vol) bulk aerosol system and a filter pack. Daily hi-vol samples were collected on Whatman-41 filters under conditions very similar to those used historically for most marine boundary layer sampling [e.g., Savoie et al., 1990]. Semi daily filter pack samples were collected in parallel with the hi-vol samples. In the filter pack the particulate $\mathrm{NO}_{3}^{-}$was collected on a quartz fiber filter and the volatile $\mathrm{NO}_{3}^{-}$on a $\mathrm{K}_{2} \mathrm{CO}_{3}$-glycerol impregnated rayon filter. Additional details about these systems are given by Pszenny et al. [1990b] and Keene et al. [1990]. The University of Virginia (UVA) and NOAA Environmental Research Laboratories (ERL) ran a single filter pack on the ship measuring particulate $\mathrm{NO}_{3}^{-}$on a Teflon filter and volatile $\mathrm{NO}_{3}^{-}$, also on an impregnated rayon filter [Bardwell et al., 1990]. Intercomparison of the sea salt concentrations between the various systems suggested that approximately two thirds of the sea salt, by mass, was excluded by the AOML inlet and approximately $20 \%$ was excluded by the UVA sampler [Boatman et al., 1990]. The AOML analyzed some of their filters at sea, but most of the filters were stabilized, stored and returned to the laboratory for quantitative $\mathrm{NO}_{3}^{-}$analysis using ion chromatography. Detailed procedures are given by Anlauf et al. [1985], Pszenny et al. [1990b], Keene et al. [1990] and Bardwell et al. [1990]. Two UVA/ERL filter pack systems were deployed on the aircraft, and the samples were analyzed identically to the ship samples. For one of the aircraft systems a cyclone was used to exclude particles of radius greater than $0.4 \mu \mathrm{m}$.

\section{RESULTS AND DISCUSSION}

\section{Distinguishing Between Continental and Marine Air Masses}

One of the objectives of this experiment was to determine the concentrations of reactive nitrogen species in the Atlantic marine atmosphere. This requires that air which has recently passed over a continent be identified.

For the first leg of the cruise the meteorology over the western Atlantic Ocean was dominated by a large highpressure system which was centered in the vicinity of Bermuda and covered most of the North Atlantic Ocean (the so-called Bermuda High). As a result the air sampled at the ship would likely have come from over the ocean to the east in moving clockwise around this high. This conclusion is supported by both the isobaric and isotropic trajectories calculated for the ship's position [Stunder et al., 1990]. However, when the ship was close to the North American coast, the air actually passed over the continent before being sampled at the ship. Thus on the early part of the cruise the shipboard instruments were sampling air heavily impacted by the continent, but as the ship travelled eastward the sampled air no longer contacted the continent. Trajectories in these latter cases indicated a residence time over the ocean of more than $\mathbf{5}$ days, and so the composition of the air was typical of that over large areas of the western North Atlantic Ocean. The date when the sampled air was no longer impacted by the continent is difficult to ascertain precisely from the trajectories but appears to be around July 20 (Julian day 202).

Two tracer methods were used to give a better determination of the time of this transition: radon and black carbon. Radon 222 is only emitted from land surfaces and has a radioactive decay half-life of $\mathbf{3 . 8}$ days. Thus, it is a very good indicator of an air mass that has recently been in contact with land. Radon 222 was measured on this mission; and the data are discussed in detail by Hansen et al. [1990]. Figure 3 shows the radon measurements for the Virginia to Bermuda leg. As expected, the radon concentration close to shore was over $10 \mathrm{pCi} \mathrm{m}^{-3}$, showing the air mass being sampled to be of recent continental origin. The radon concentration dropped rapidly as the distance from the coast increased and became approximately constant with an average of $1.9 \mathrm{pCi} \mathrm{m}^{-3}$ after July 19 (Julian day 201). Consequently, 0000 GMT on July 20 was used as a conservative estimate of the transition from continentally influenced air to marine air. The black carbon data [Hansen et al., 1990] support this assignment. Black carbon can come only from combustion, and as the bulk of this occurs over land, these data can also be used as an indicator of continental influence. The average black carbon concentration was $307 \mathrm{ng} \mathrm{m}^{-3}$ prior to July 20 but only 14.8 $\mathrm{ng} \mathrm{m}^{-3}$ afterward, supporting the classification assigned using the radon 222 data.

In this paper, data prior to July 20 (Julian day 202) are classified as continentally influenced and data collected after this date are classified as representative of the marine air mass over the western North Atlantic Ocean. 


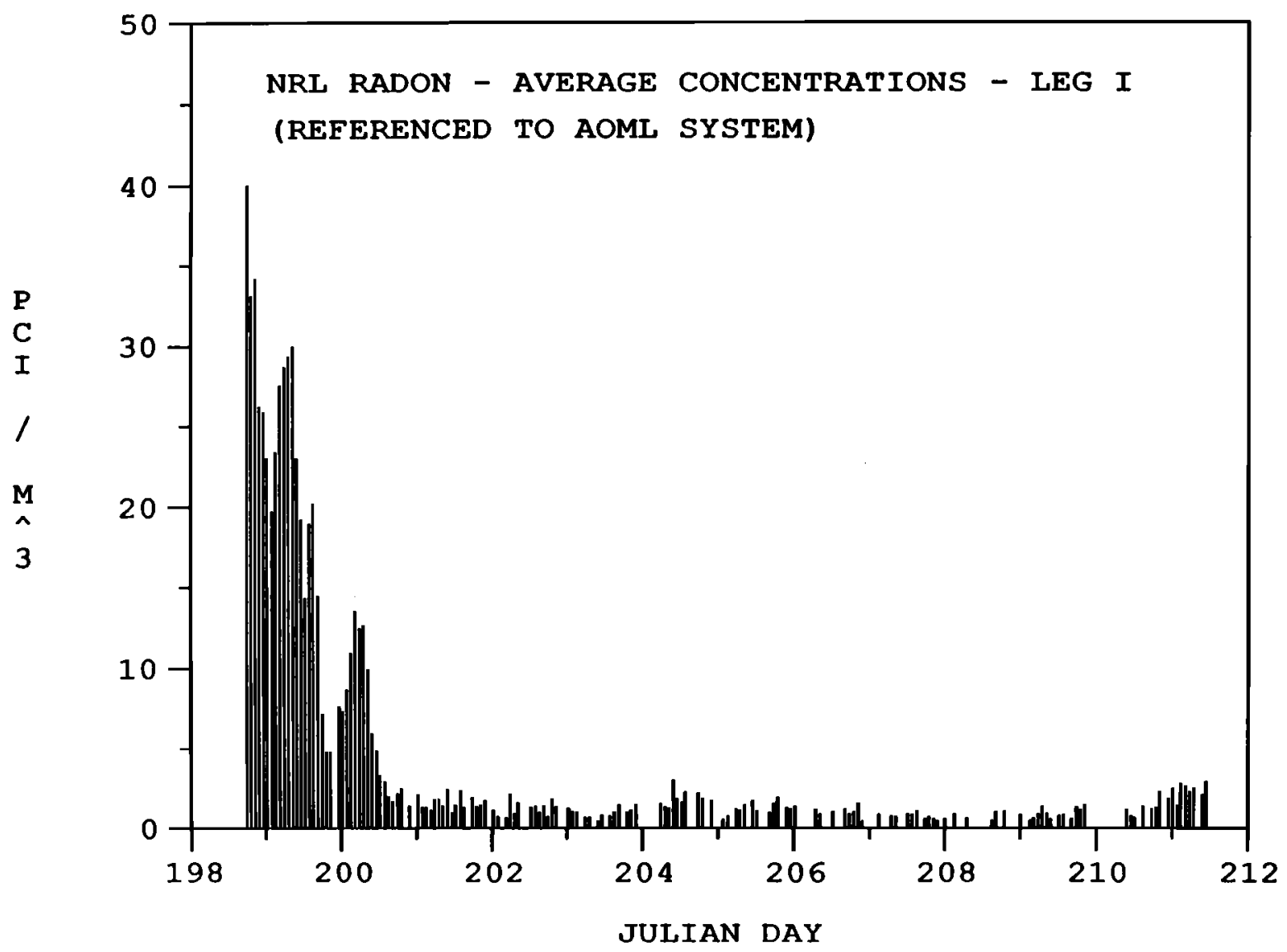

Fig. 3. Radon measurements from the first leg of the Global Change cruise.

Volatile Nitrate and Particulate Nitrate

Measurements and the Evidence

for Sea Salt Interaction

There is a substantial body of literature indicating that a number of acidic gas phase species can interact with the alkaline sea salt aerosol released from the ocean's surface. Finlayson-Pitts [1983] and Finlayson-Pitts et al. [1988, 1989] have shown in laboratory experiments that $\mathrm{NO}_{2}$, ClONO${ }_{2}$, and $\mathrm{N}_{2} \mathrm{O}_{5}$ react with sea salt to yield nitrosyl halides (XNO X= Cl, Br), $\mathrm{Cl}_{2}$, and $\mathrm{ClONO}_{2}$ respectively. Brimblecombe and Clegg [1988] used thermodynamic considerations to show that $\mathrm{HNO}_{3}$ would be expected to displace $\mathrm{HCl}$ when dissolved in a very low $\mathrm{pH}$ (1-3) sea salt aerosol droplet. Although there is not yet any evidence that the reactions found by Finlayson-Pitts et al. play a significant part in the marine boundary layer chemistry and the aerosol is generally not sufficiently acidic for the simple displacement of $\mathrm{HCl}$ [see Keene et al., 1990] marine aerosol measurements do show a strong interaction between volatile $\mathrm{NO}_{3}^{-}$and the marine aerosol. Savoie and Prospero [1982] and Church et al. [1990] are two of a number of studies that have found that a large proportion of the particulate $\mathrm{NO}_{3}^{-}$ resides in the coarse aerosol fraction, namely, the sea salt fraction.
Any interaction between volatile $\mathrm{NO}_{3}^{-}$and sea salt would have a significant impact on the nitrogen budget in the marine boundary layer, as it would remove the gas phase $\mathrm{NO}_{3}^{-}$and sequester it on particles with short atmospheric lifetimes, 2 days or so [Kritz and Rancher, 1980]. Examination of the data obtained in this study provides support for at least an interaction between the sea salt aerosol and volatile $\mathrm{NO}_{3}^{-}$.

The UVA/ERL group gathered particulate and volatile $\mathrm{NO}_{3}^{-}$data from both the ship and from the aircraft and additionally with particle size segregation from the aircraft. Only the UVA/ERL data set is considered here, as it is the only one that has altitude information. There is little gain in precision in supplementing the shipboard measurements with those of the other groups. Table 1 summarizes the UVA/ERL inorganic $\mathrm{NO}_{3}^{-}$measurements. The data are grouped by sampling height and by sampling system, and within each of these classifications into continentally influenced and marine air. The aircraft measurements out of Bermuda are listed as a special case. The means with their standard deviations and the medians are plotted in Figure 4.

Concentration measurements are available from three altitudes, at $16 \mathrm{~m}$ above the sea surface as measured from the ship, and from 152 and $2591 \mathrm{~m}$ as measured from the 
TABLE 1. UVA/ERL Volatile and Particulate Nitrate Measurements

\begin{tabular}{|c|c|c|c|c|c|c|c|c|c|}
\hline \multirow[t]{2}{*}{$\begin{array}{c}\text { Altitude } \\
\text { m }\end{array}$} & \multirow[t]{2}{*}{ Air Mass } & \multirow[t]{2}{*}{$\begin{array}{c}\text { Size } \\
\text { Fraction }\end{array}$} & \multicolumn{2}{|c|}{$\begin{array}{c}\text { Particulate } \\
\text { Nitrate, } \mathrm{nmol} \mathrm{m}^{-3}\end{array}$} & \multicolumn{2}{|c|}{$\begin{array}{c}\text { Gas Phase } \\
\text { Nitrate, } \text { nmol m-3 }^{-3}\end{array}$} & \multicolumn{2}{|c|}{$\begin{array}{c}\text { Gas Phase to Total } \\
\text { Nitrate Ratio nmol m } \\
\end{array}$} & \multirow[t]{2}{*}{$\begin{array}{l}\text { No. of } \\
\text { Points }\end{array}$} \\
\hline & & & $\overline{\text { Mean (s.d.) }}$ & Median & Mean (s.d.) & Median & Mean (s.d.) & Median & \\
\hline 16 & Continental & Total & $15.6(6.1)$ & 14.1 & $17.3(22.7)$ & 2.2 & $0.31(0.26)$ & 0.15 & 6 \\
\hline 16 & Marine & Total & $6.9(2.4)$ & 6.6 & $2.2(1.6)$ & 1.5 & $0.24(0.13)$ & 0.22 & 14 \\
\hline 152 & Continental & Fine & $4.4(1.7)$ & 4.8 & $12.5(13.6)$ & 7.1 & $0.57(0.30)$ & 0.64 & 4 \\
\hline 152 & Continental & Total & $8.7(4.7)$ & 7.7 & $15.1(12.1)$ & 10.9 & $0.57(0.18)$ & 0.46 & 6 \\
\hline 152 & Marine & Fine & $2.1(0.2)$ & 2.1 & $1.2(0.2)$ & 1.2 & $0.36(0.08)$ & 0.36 & 2 \\
\hline 152 & Marine & Total & $4.3(0.1)$ & 4.3 & $2.0(0.4)$ & 2.0 & $0.32(0.04)$ & 0.32 & 2 \\
\hline 152 & Marine (BDA) & Fine & $0.60(0.4)$ & 0.41 & $1.8(2.8)$ & 0.58 & $0.56(0.25)$ & 0.62 & 8 \\
\hline 152 & Marine (BDA) & Total & $1.0(0.3)$ & 0.92 & $2.2(0.4)$ & 2.4 & $0.68(0.07)$ & 0.68 & 8 \\
\hline 2591 & Continental & Total & $1.6(0.3)$ & 1.7 & $12.0(4.2)$ & 11.2 & $0.88(0.88)$ & 0.90 & 3 \\
\hline 2591 & Marine & Total & $1.3(\mathrm{~N} / \mathrm{A})$ & 1.3 & 1.7 (N/A) & 1.7 & $0.56(\mathrm{~N} / \mathrm{A})$ & 0.56 & 1 \\
\hline 2591 & Marine (BDA) & Total & $0.64(0.1)$ & 0.58 & $2.5(1.1)$ & 2.7 & $0.75(0.16)$ & 0.82 & 4 \\
\hline
\end{tabular}

BDA, Bermuda

aircraft on its constant-altitude legs. Data from the cycloneseparated samples on the aircraft are only available for the lower aircraft sampling altitude (152 $\mathrm{m}$ ) and are shown in Figure 4a. The degree to which the upper level air mass is related to the lower two is not that clear. Rawinsondes flown from the ship [Stunder et al., 1990] showed there to be a strong and persistent inversion at about $700 \mathrm{mb}$ $(\sim 3000 \mathrm{~m})$ with weak and erratic inversions in the $500 \mathrm{~m}$ to $2 \mathrm{~km}$ altitude range. The two lowest sampling altitudes are clearly within the marine boundary layer, but it may well be the case that some of the highest-altitude measurements may also be on air from within the marine boundary layer, although this is not supported by the aerosol measurements where the measured sea salt was always below detection limits.

Comparison of the aircraft data from the sample restricted to the fine aerosol fraction (Table 1 and Figure 4a) and the total aerosol (Table 1 and Figure 4c) show the volatile $\mathrm{NO}_{3}^{-}$ to be lower in the fractionated sample than in the unperturbed sample. As the volatile $\mathrm{NO}_{3}^{-}$measured must be gas phase to pass through the first filter, these results suggesting a small loss of volatile $\mathrm{NO}_{\mathbf{3}}^{-}$, probably on the walls of the cyclone itself [see Bardwell et al., 1990]. Much more noticeable are the differences in the particulate $\mathrm{NO}_{3}^{-}$concentrations. In all three cases there is approximately half the particulate $\mathrm{NO}_{3}^{-}$in the fine fraction aerosol compared with that in the total sample. This points to the measured particulate $\mathrm{NO}_{3}^{-}$being more abundant on the larger particles and is consistent with the observations in the literature [e.g., Savoie and Prospero, 1982; Church et al., 1990].

Further information comes from the variation in sodium, particulate $\mathrm{NO}_{3}^{-}$, and volatile $\mathrm{NO}_{3}^{-}$with altitude. As the altitude increases, the concentrations of sodium decrease markedly. This is due largely to the sea surface source and large size of the sea salt particles and their high settling velocity, although there may also be a decrease in the collection efficiency of the large particles. The concentrations of the particulate $\mathrm{NO}_{3}^{-}$also decrease markedly, whereas those of the volatile $\mathrm{NO}_{3}^{-}$remain almost unchanged. This again supports the contention that a large fraction of the particulate $\mathrm{NO}_{3}^{-}$is associated with the sea salt. This also means that the distribution of the inorganic $\mathrm{NO}_{3}^{-}$between the gas and particle phases is not the same at all altitudes within the marine boundary layer. Figure 5 shows, in both the mean and median values, that there is an increase of a factor of 2 in the gas phase $\mathrm{NO}_{3}^{-}$to total $\mathrm{NO}_{3}^{-}$ ratio between the ship data and the $152 \mathrm{~m}$ aircraft data and a further $50 \%$ in going to $2591 \mathrm{~m}$. This strongly supports an interaction between the volatile $\mathrm{NO}_{3}^{-}$and the sea salt aerosol. It is not possible to tell from these data alone whether this interaction is a simple adsorption or a true volatile $\mathrm{NO}_{3}^{-}$to particulate $\mathrm{NO}_{3}^{-}$conversion.

This observation also has implications for the measurement of volatile and particulate nitrate in the marine environment. It is possible that once sea salt aerosol is present on a filter it can remove volatile $\mathrm{NO}_{3}^{-}$from the air sample, and thus inorganic $\mathrm{NO}_{3}^{-}$that was present in the air as volatile $\mathrm{NO}_{3}^{-}$ may be measured as particulate $\mathrm{NO}_{3}$ (see also Keene et al. [1990]). This effect is in the opposite direction to the wellknown production of volatile nitrate from the volatilization of ammonium nitrate aerosol which is unlikely to be important in this case as the ammonium nitrate concentration is expected to be low. The extent of this problem will depend on the homogeneity of the environment over the sampling period. If the volatile $\mathrm{NO}_{3}^{-}$is in equilibrium with the sea salt prior to sampling and if the air mass is homogeneous in both inorganic nitrate and sea salt, then 
(a)
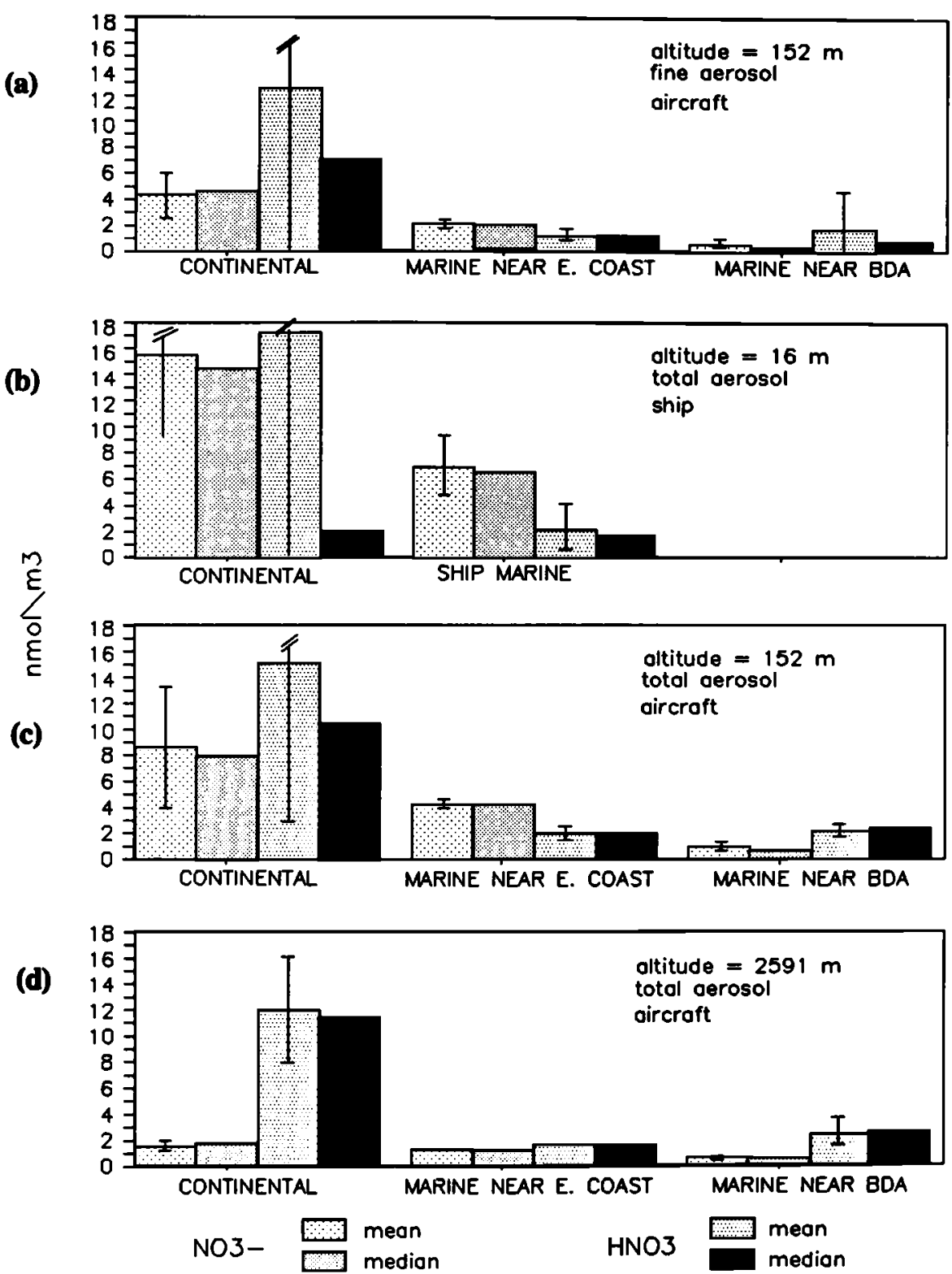

Fig. 4. Volatile and particulate nitrate measurements as measured from the ship and the aircraft. Shown are the mean concentrations with the standard deviations, and the median concentrations classified by region - (a) aircraft fine aerosol fraction, $150 \mathrm{~m}$, (b) ship total aerosol, $16 \mathrm{~m}$, (c) aircraft total aerosol, $150 \mathrm{~m}$, and (d) aircraft total aersol, $2591 \mathrm{~m}$.

there will be no further interaction on the filter. A change in the concentrations or any conditions that govern the equilibrium processes could lead to errors in the measured partitioning between volatile and particulate nitrate. In environments where there is a large amount of volatile $\mathrm{NO}_{3}^{-}$ or low sea salt concentrations, or for samples with low loadings, the bias should be small. Care must therefore be taken, in a sea-salt-rich environment, in using filter pack data to quantitatively differentiate between gas and particulate $\mathrm{NO}_{3}^{-}$. The measured particulate $\mathrm{NO}_{3}^{-}$should be considered an upper limit and the volatile $\mathrm{NO}_{3}^{-}$a lower limit.

\section{Concentrations of the Inorganic} Nitrogen Species

Reactive nitrogen. Figure 6 shows the concentrations of $\mathrm{NO}_{2}, \mathrm{NO}_{\mathrm{x}}$, and $\mathrm{NO}_{\mathrm{y}}$ as measured from the ship on leg 1 . 

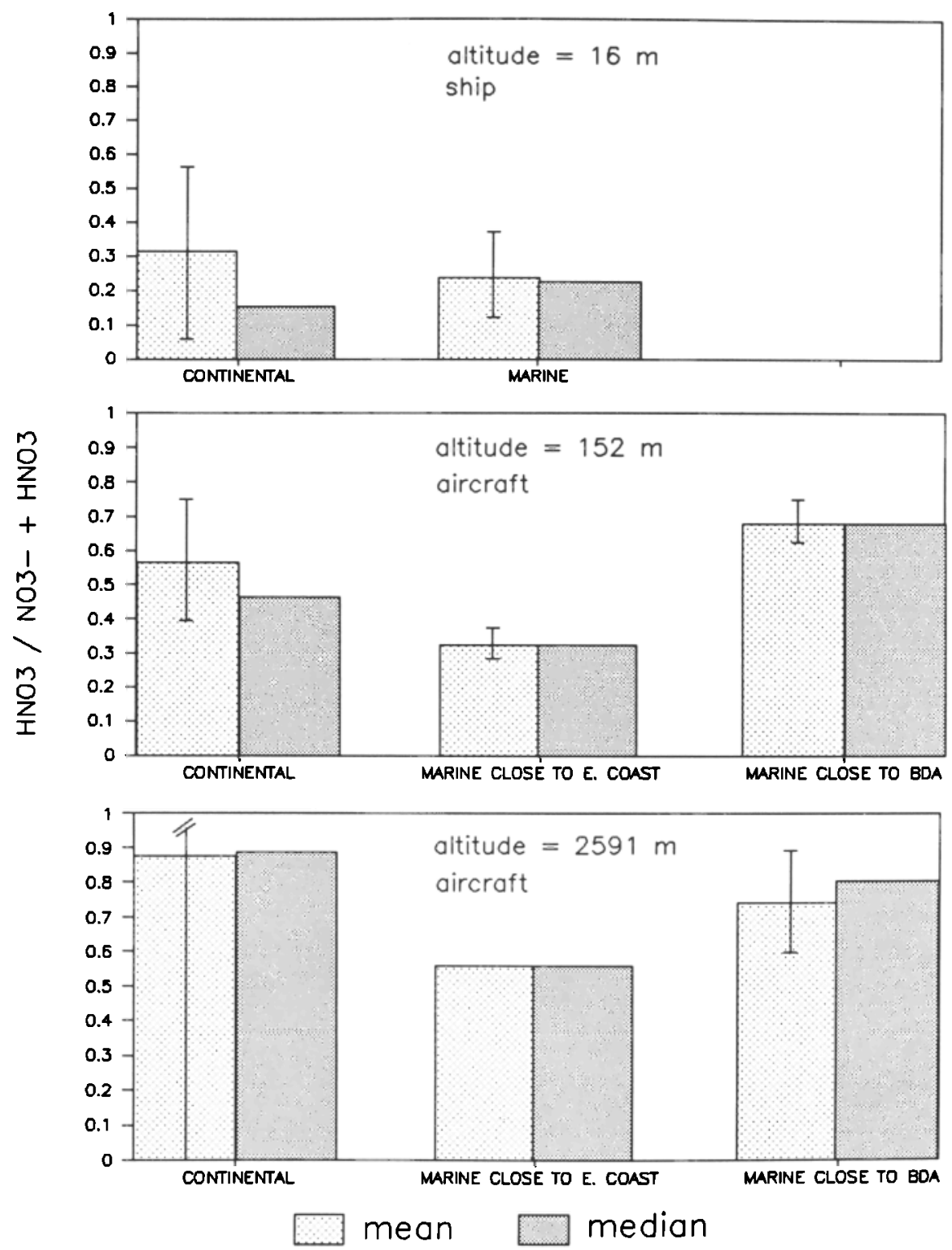

Fig. 5. The fraction of the inorganic nitrate collected as nitric acid. The mean and standard deviation along with the median of simultaneously collected samples are given.

The instrument was not operated for the first day out of port to prevent contamination by the very polluted air of the Norfolk port area. The highest concentrations were encountered on the first few days of the cruise when the continentally influenced air was sampled. The concentrations decreased as the distance from the continental source increased owing to the combination of dispersion, transformation, and deposition processes.

The data after July 20 (day 202) are considered to be characteristic of North Atlantic marine background and should yield an estimate of the marine reactive nitrogen concentrations over the Western North Atlantic Ocean.
However, before the discussion of these concentrations it should be noted that while the concentrations are generally uniform, there are two features that require comment.

The $\mathrm{NO}_{\mathrm{y}}$ concentrations go through a minimum on Julian day 200 rising to a much higher concentrations on Julian days 201 and 202 (July 20-21) then decreasing for the following 7 days, whereas the changes in $\mathrm{NO}_{x}$ and $\mathrm{NO}_{2}$ over this period were much smaller. By all previous arguments, the air after July 20 was free of continental influence and would be expected to show similar $\mathrm{NO}_{\mathrm{y}}$ concentrations over this period. Intercomparisons with the $\mathrm{NO}_{\mathrm{y}}$ monitor on the aircraft were performed on July 19 and 


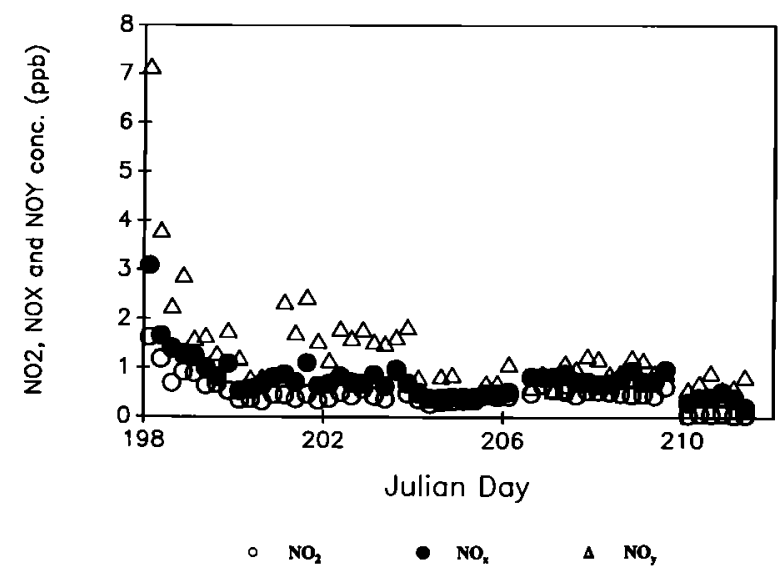

Fig. 6. Reactive nitrogen measurements from the first leg of the cruise.
21. Agreement was good for these days and for the remainder of leg 1 [Boatman et al., 1990]. There was, however, poor agreement between the instruments on July 17 and 18 , when the continentally influenced air was sampled. Thus the shipboard $\mathrm{NO}_{\mathrm{y}}$ data from July 17 to 19 must be viewed with some caution, and the minimum at day 200 may be due to an instrument problem on the ship.

The second notable feature of the data is the sharp drop in the concentrations of all the reactive nitrogen species on July 28 commencing at around midnight. An intercomparison with the aircraft instrument on July 28 showed continued good agreement between the instruments and ruled out an instrumental problem with these data. This decrease was coincident with decreases in ozone and CN (S. Piotrowicz, private communication, 1989; H. Sievering, private communications, 1989) as well as with an increase in sea salt mass, and with the fraction of sulphate on the coarse fraction aerosol. These data suggest a change in air

TABLE 2. Marine Nitrogen Concentrations at Sea Level

\begin{tabular}{|c|c|c|c|c|}
\hline \multirow[b]{2}{*}{ Source } & \multicolumn{4}{|c|}{ Concentration, nmol m ${ }^{-3}$} \\
\hline & $\mathrm{NO}_{2}$ & $\mathrm{NO}_{\mathrm{x}}$ & $\mathrm{NO}_{\mathrm{y}}$ & Inorganic $\mathrm{NO}_{3}^{-}$ \\
\hline $\begin{array}{l}\text { Carroll et al. [1990] } \\
\text { (Pacific Ocean) }\end{array}$ & 0.46 & 0.62 & & \\
\hline $\begin{array}{l}\text { Hastie et al. [1988] } \\
\text { (Bermuda data) }\end{array}$ & & $44(17)$ & & $17(10)^{*}$ \\
\hline $\begin{array}{l}\text { Wolff et al. [1986] } \\
\text { (Bermuda winter) } \\
\text { (Bermuda summer) }\end{array}$ & & $\begin{array}{l}<39 \\
<30\end{array}$ & & $\begin{array}{l}10^{*} \\
10^{*}\end{array}$ \\
\hline $\begin{array}{l}\text { Misanchuk et al. [1987] } \\
\text { (Atlantic Ocean) }\end{array}$ & & $130(108)$ & & \\
\hline $\begin{array}{l}\text { Luke and Dickerson [1987] } \\
\text { (Atlantic Ocean) }\end{array}$ & & 55.3 & & \\
\hline $\begin{array}{l}\text { Whelpdale et al. [1987] } \\
\text { (Atlantic Ocean) }\end{array}$ & & & & $11.1(2.6)^{*}$ \\
\hline $\begin{array}{l}\text { This work } \\
\text { (AES) } \\
\text { (UVA) } \\
\text { (AOML) }\end{array}$ & $18(8.5)$ & $29(9.4)$ & $46(17)$ & $\begin{array}{l}11.2(4.8)^{*} \\
9.8(2.8)^{*} \\
8.1(2.8)^{*}\end{array}$ \\
\hline $\begin{array}{l}\text { Savoie et al. [1990] } \\
\text { (North Pacific) } \\
\text { (South Pacific) }\end{array}$ & & & & $\begin{array}{l}5.2^{\dagger} \\
3.2^{\dagger}\end{array}$ \\
\hline
\end{tabular}

Standard deviations, where available, are given in parentheses.

* Obtained by summing the particulate and volatile nitrate concentrations.

$\dagger$ Particulate measurement only assuming gas phase scavenged by the collected particulate. 


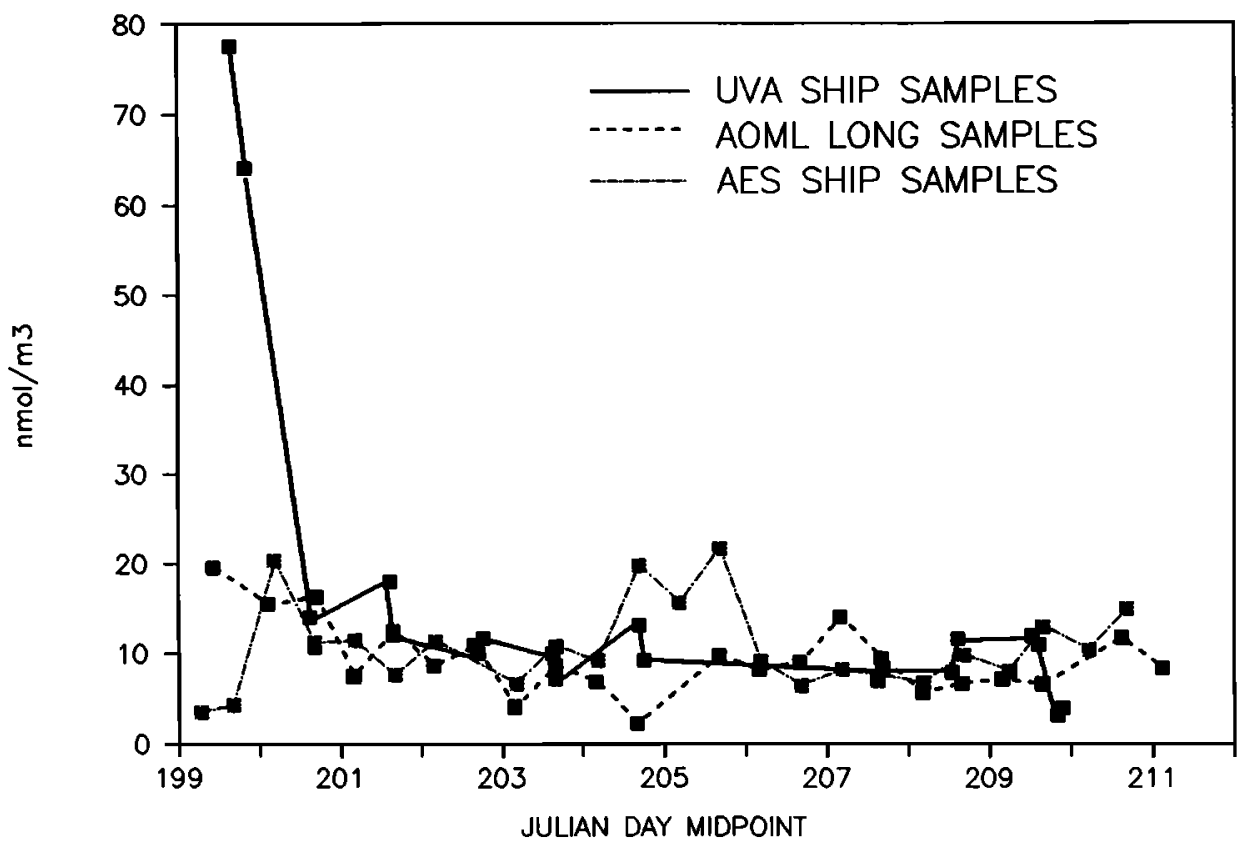

Fig. 7. Total inorganic nitrate (particulate nitrate and nitric acid) as measured by all the groups active on the first leg of the cruise.

mass, or a change in local meteorology with an increase in wind speed, although the trajectories and weather maps give no such indication.

To obtain average marine reactive nitrogen concentrations over the western North Atlantic Ocean, all data after Julian day 202 have been averaged. These are presented in Table 2 along with some previous marine measurements for comparison. The concentrations are lower than those previously measured in marine air over the western Atlantic Ocean [Misanchuk et al., 1987; Luke and Dickerson, 1987], and at Bermuda [Hastie et al., 1988 and Wolff et al., 1986]. This is likely because these previous measurements were made in the winter, when there was a strong westerly flow carrying material from the continent over the ocean. The measurements of Misanchuk et al. [1987] were made within $50 \mathrm{~km}$ of the North American coast and so were even more strongly impacted by the transport of continental nitrogen emissions.

The concentrations reported here are much higher than those measured over the Pacific Ocean [Carroll et al., 1990; McFarland et al., 1979]. On the NASA Chemical Instrument Test and Evaluation (CITE) 2 program the average $\mathrm{NO}_{\mathrm{x}}$ concentration was $0.014 \mathrm{ppbv}\left(0.62 \mathrm{nmol} \mathrm{m}{ }^{-3}\right)$ in the marine boundary layer [Carroll et al., 1990]. Even these levels are thought to be above the natural Pacific Ocean marine background, due to air circulating from the continent to the aircraft several hundred miles offshore. McFarland et al. [1979] measured NO concentrations of 4 pptv from a ship in the mid-Pacific. Thus it is apparent that the reactive nitrogen encountered over the western Atlantic Ocean in this study is $\mathbf{4 0}$ to $\mathbf{5 0}$ times higher than that found in the marine boundary layer over the Pacific Ocean. As the ocean is not a significant source of oxidized nitrogen
[Liu et al., 1983], this indicates that the surrounding continents are a major source of reactive nitrogen over the Atlantic Ocean.

The marine reactive nitrogen concentrations measured here are for summer and for air that has been over the ocean for more than 5 days. The measurements of Luke and Dickerson [1987] are for the winter when there was a strong flow off the continent, so the time that the air had spent over the ocean was only 1-2 days. There is, however, less than a factor of 2 difference in the reactive nitrogen concentration between these two regimes, and the reactive nitrogen concentration is still more than an order of magnitude above the probable background concentration [Carroll et al., 1989]. This difference cannot be explained by the small continental seasonal variation in the nitrogen sources and, as there are believed to be no oceanic sources, points toward large continental sources and a several-day lifetime for the reactive nitrogen species.

Inorganic nitrate. Figure 7 shows the concentrations of inorganic (gas and particulate) $\mathrm{NO}_{3}^{-}$as measured by each of the three groups, operating $\mathrm{NO}_{3}^{-}$systems on the first leg of the cruise. On the first day of measurements the UVA/ERL group measured much higher $\mathrm{NO}_{3}^{-}$than those of the other groups, but by July 18 and for the remainder of leg 1 the measurements of total $\mathrm{NO}_{3}$ agreed well (see Figure 7). For the marine samples the measured concentrations were very consistent from sample to sample and between groups. The averaged marine total $\mathrm{NO}_{3}^{-}$concentration over all three groups are given in Table 2 along with other reported values. The values reported here are similar to those reported over the Atlantic Ocean by Whelpdale et al. [1987] and for Bermuda by Hastie et al. [1988] and Wolff et al. [1986]. Savoie et al. [1990] report annually averaged total 
$\mathrm{NO}_{3}^{-}$concentrations throughout the Pacific Ocean. These data were collected on a single particulate filter which was assumed to collect all the particulate nitrate and scavenge any of the small amount of volatile nitrate thought to be present. If there was a significant amount of volatile nitrate in the sampled air, then this assumption is not valid and the data yield only a lower limit for the total nitrate. In these environments, volatile nitates are thought to be much lower in concentration than the particulate nitrates, so the data are then directly comparable with those obtained in this study. Savoie et al. [1990] report nitrate concentrations in the remote North Pacific approximately a factor of 2 lower than those reported here for the western Atlantic Ocean and remote South Pacific concentrations approximately a factor of 3 lower. As with the reactive nitrogen species, this suggests that the air over the western Atlantic Ocean is much more heavily impacted by the emissions from the surrounding continents than is the Pacific Ocean. While this data set is small and limited in spatial and temporal coverage compared with the extensive data of Savoie et al. [1990], the indications are that there is only a small difference in total inorganic $\mathrm{NO}_{3}^{-}$between the oceans when compared to the difference in the reactive nitrogen precursors, namely, a factor of 3 compared to a factor of 40. This difference may be explained by a slow conversion of reactive nitrogen into $\mathrm{NO}_{3}^{-}$and a much faster process removing this $\mathrm{NO}_{3}^{-}$from the marine boundary layer.

\section{CONCLUSIONS}

The concentration of nitrogen species over the western North Atlantic Ocean is elevated compared with remote marine areas, likely because of the advection of emitted materials from the continents. Both the reactive species, such as $\mathrm{NO}_{2}$ and $\mathrm{NO}_{\mathrm{x}}$, and the less reactive but more readily deposited inorganic nitrates are found in higher amounts. The reactive species are present at approximately 40 times the concentration found over the Pacific and the total $\mathrm{NO}_{3}^{-}$at a factor of 1.5 to 3 higher, suggesting that the rate of $\mathrm{NO}_{3}^{-}$loss over the ocean is fast compared to the production of the $\mathrm{NO}_{3}^{-}$from the reactive precursors.

The distribution of inorganic $\mathrm{NO}_{3}^{-}$between particulate and volatile phases appears to have a strong dependence on altitude. A much higher fraction of the $\mathrm{NO}_{3}^{-}$is in the particulate phase at lower altitudes where the sea salt concentration is higher. This suggests a strong interaction of volatile $\mathrm{NO}_{3}^{-}$with the sea salt aerosol. Aircraft sampling at a greater number of altitudes would give greater insight into the processes responsible. This interaction also has implications for the measurement of these species using filter pack systems. The volatile and particulate $\mathrm{NO}_{3}^{-}$can both be quantitatively determined in the following cases: if the concentrations are homogenous throughout the sampling period, if the volatile $\mathrm{NO}_{3}^{-}$concentration is high or the sea salt concentration low, or where the filter loading is low. In other cases there is the possibility of the filter packs giving an erronous partitioning so that only the total inorganic $\mathrm{NO}_{3}^{-}$can be determined.

Acknowledgments. We thank Captain D. E. Nortrup and the crew of the NOAA ship Mt. Mitchell for their invaluable assistance and patience on the Global Change Expedition; B. Martin, T. Ferdleman, and S. Melnichuk for the operation of the $\mathrm{NO}_{\mathrm{x}}$ analyzer; and R. Artz, J. Harris, and $J$. Merrill for trajectory information and interpretation of the meteorology. This work was supported in part by the Atmospheric Environment Service of Environment Canada, the NOAA Radiatively Important Trace Species (RITS) program, and the NOAA Western Atlantic Ocean Experiment (WATOX).

\section{REFERENCES}

Anlauf, K. G., P. Fellin, H. A. Wiebe, H. I. Schiff, G. I. Mackay, R. S. Braman, and R. Gilbert, Methods for measurement of atmospheric nitric acid and aerosol nitrate and ammonium, Atmos. Environ., 19, 325-333, 1985.

Bardwell, C. A., J. R. Maben, J. A. Hurt, W. C. Keene, J. N. Galloway, J. F. Boatman, and D. Wellman, A technique utilizing high-flow, dichotomous filter packs for measuring atmospheric chemical constituents, Global Biogeochem. Cycles, in press, 1990.

Boatman, J. F., W. C. Keene, M. Luria, J. D. Ray, C. A. Bardwell, K. Gorzelska, M. Fennell, D. R. Hastie, A. A. P. Pszenny, and D. M. Whelpdale, An intercomparison of the chemical and meteorological data collected from aircraft and shipboard sampling during GCE/CASE/WATOX, NOAA Tech. Memo, Environ. Res. Lab., Natl. Oceanic and Atmos. Admin., Silver Spring Md., in press, 1990.

Bottenheim, J. W., and A. J. Gallant, The occurrence of peroxyacetyl nitrate over the Atlantic Ocean east of North America during WATOX-86, Global Biogeochem. Cycles, 1, 369-380, 1987.

Brimblecombe, P., and S. L. Clegg, The solubility and behaviour of acid gases in the marine aerosol, J. Atmos. Chem., 7, 1-18, 1988.

Carroll, M. A., et al., Aircraft measurements of $\mathrm{NO}_{\mathrm{x}}$ over the eastern Pacific and continental United States and implications for ozone production, J. Geophys. Res., 95, 10,205-10,233, 1990.

Church, T. M., J. M. Tramontano, D. M. Whelpdale, M. O. Andreae, J. N. Galloway, W. C. Keene, A. H. Knap, and J. Tokos, Jr., Atmospheric and precipitation chemistry over the North Atlantic Ocean: Shipboard results from April-May 1984, J. Geophys. Res., in press, 1990.

Drummond, J. W., C. Castledine, J. Green, R. Denno, G. I. Mackay, and H. I. Schiff, New technologies for use in acid deposition networks, in Monitoring Methods for Toxics in the Atmosphere, ASTM STP 1052, edited by W. L. Zielinski, 133-149 Am. Soc. for Test. and Mater., Philadelphia, Pa., 1989.

Drummond, J. W., D. H. Ehhalt, and A. Voltz, Measurements of nitric oxide between 0-12 km altitude and $67^{\circ} \mathrm{N}$ to $60^{\circ} \mathrm{S}$ latitude obtained during STRATOZ III, J. Geophys. Res., 93, 15,831-15,849, 1988.

Fahey, D. W., C. S. Eubank, G. Hübler, and F. C. Fehsenfeld, Evaluation of a catalytic reduction technique 
for the measurement of total reactive odd-nitrogen $\mathrm{NO}_{\mathrm{y}}$ in the atmosphere, J. Atmos. Chem., 3, 435-468, 1985.

Finlayson-Pitts, B. J., Reaction of $\mathrm{NO}_{2}$ with $\mathrm{NaCl}$ and atmospheric implications of $\mathrm{NOCl}$ formation, Nature, 306, 676-677, 1983.

Finlayson-Pitts, B. J., and S. N. Johnson. The reaction of $\mathrm{NO}_{2}$ with $\mathrm{NaBr}$ : Possible source of $\mathrm{BrNO}$ in polluted marine atmospheres, Atmos. Environ., 22, 1107-1112, 1988.

Finlayson-Pitts, B. J., M. J. Ezell, and J. N. Pitts, Jr., Formation of chemically active chlorine compounds by reactions of atmospheric $\mathrm{NaCl}$ particles with gaseous $\mathrm{N}_{2} \mathrm{O}_{5}$ and $\mathrm{ClONO}_{2}$, Nature, 337, 241-244, 1989.

Galloway, J. N., and D. M. Whelpdale, WATOX-86 overview and western North Atlantic Ocean S and N atmospheric budgets, Global Biogeochem. Cycles, 1, 261281, 1987.

Galloway, J. N., T. M. Church, A. H. Knap, D. M. Whelpdale, and J. M. Miller, The Western Atlantic Ocean Experiment, in The Chemistry of Acid Rain Sources and Atmospheric Processes edited by R. W. Johnson, 39-55, American Chemical Society, New York, 1987.

Hansen, A. D. A., R. S. Artz, A. A. P. Pszenny, and R. E. Larson, Aerosol black carbon and radon as tracers for air mass origin over the westem Atlantic Ocean, Global Biogeochem. Cycles, in press, 1990.

Hastie, D. R., H. I. Schiff, D. M. Whelpdale, R. Peterson, W. Zoller, and D. Anderson, Nitrogen and sulphur over the western Atlantic Ocean, Atmos. Environ., 22, 23812391, 1988.

Keene W. C., A. A. P. Pszenny, D. J. Jacob, R. A. Duce, J. N. Galloway, J. J. Schutz-Tokos, H. Sievering, and J. F. Boatman, The geochemical cycling of reactive chlorine in the marine troposphere, Global Biogeochem. Cycles, in press, 1990.

Kritz, M. A., and J. Rancher, Circulation of $\mathrm{Na}, \mathrm{Cl}$, and $\mathrm{Br}$ in the tropical marine atmosphere, J. Geophys. Res., 85, 1633-1639, 1980.

Levy, H., II, The AEROCE project, in Tropospheric Ozone, Regional and Global Scale Interactions, NATO ASI Ser. C, vol. 227, edited by I. S. A. Isaksen, 365370, D. Reidel, Mingham, Mass., 1988.

Liu, S. C., M. McFarland, D. Kley, O. Zafiriou, and B. Huebert, Tropospheric $\mathrm{NO}_{x}$ and $\mathrm{O}_{3}$ budgets in the equitorial Pacific, J. Geophys. Res. , 88, 1360-1368, 1983.

Luke, W. T., and R. R. Dickerson, The flux of reactive nitrogen compounds from eastern North America to the western Atlantic Ocean, Global Biogeochem. Cycles, 1, 329-343, 1987.

McFarland, M., D. Kley, J. W. Drummond, A. L. Schmeltekopf, and R. M. Winkler, Nitric oxide measurements in the equitorial pacific region, Geophys. Res. Lett. 6, 605-609, 1979.

Misanchuk, B. A., D. R. Hastie, and H. I. Schiff, The distribution of nitrogen oxides off the east coast of North America, Global Biogeochem. Cycles, 1, 345-355, 1987.
Pszenny, A. A. P., J. N. Galloway, R. S. Artz, and J. F. Boatman, Overview of the 1988 GCE/CASE/WATOX studies of biogeochemical cycles in the North Atlantic region, Global Biogeochem. Cycles, in press, 1990a.

Pszenny, A. A. P., G. R. Harvey, C. J. Brown, R. F. Long, W. C. Keene, J. N. Galloway and J.T. Merrill, Measurements of dimethylsulfide oxidation products in the summertime North Atlantic boundary layer, Global Biogeochem. Cycles, in press, $1990 \mathrm{~b}$.

Ray, J. D., M. Luria, D. R. Hastie, S. Malle, W. C. Keene, and H. Sievering, Losses and transport of odd nitrogen species $\left(\mathrm{NO}_{\mathrm{y}}\right)$ over the western Atlantic Ocean during GCE/CASE/WATOX, Global Biogeochem. Cycles, in press, 1990.

Rudolph, J., B. Vierkom-Rudolph, and F. X. Meixner, Large-scale distribution of peroxyacetylnitrate results from the STRATOZ III flights, J. Geophys. Res., 92, 6653-6661, 1987.

Savoie, D. L., and J. M. Prospero, Particle size distribution of nitrate and sulfate in the marine atmosphere, Geophys. Res. Lett., 9, 1207-1210, 1982.

Savoie, D. L., J. M. Prospero, and E. S. Saltzman, Nitrate,non-seasalt sulfate and methanesulphonate over the Pacific Ocean, in Chemical Oceanography vol. 10, edited by J. P. Riley, 230-250, Academic, San Diego, Calif., 1990.

Stunder B. J. B., R. S. Artz, G. D. Rolph, J. M. Harris, and J. T. Merrill, Summary of meterological conditions over the North Atlantic Ocean during GCE/CASE/WATOX, Global Biogeochem. Cycles, in press, 1990.

Whelpdale, D. M., W. C. Keene, A. D. A. Hansen, and J. F. Boatman, Aircraft measurements of sulfur, nitrogen and carbon species during WATOX-86, Global Biogeochem. Cycles, 1, 357-368, 1987.

Wolff, G. T., M. S. Ruthkosky, D. P. Stroup, P. E. Korsog, M. A. Ferman, G. J. Wendel, and D. H. Stedman, Measurements of $\mathrm{SO}_{\mathrm{x}}, \mathrm{NO}_{\mathrm{x}}$ and aerosol species on Bermuda, Atmos. Environ., 20, 1229-1239, 1986.

J. N. Galloway, W. C. Keene, and J. Maben, Department of Environmental Sciences, University of Virginia, Charlottesville, VA 22903.

D. R. Hastie, S. Malle, and D. L. Toom, Department of Chemistry, York University, 4700 Keele Street, North York, Ontario, Canada M3J 1P3.

A. A. P. Pszenny, Ocean Chemistry Division, NOAA AOML, 4301 Rickenbacker Causeway, Miami, FL 33149.

D. M. Whelpdale, Atmospheric Environment Service, 4905 Dufferin Street, North York, Ontario, Canada M3H $5 T 4$.

(Received June 8, 1990; revised September 19, 1990; accepted September 24, 1990.) 